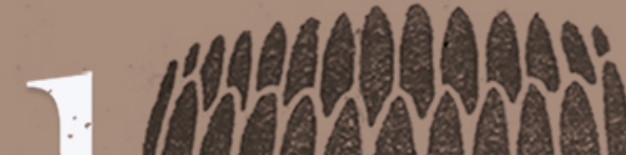

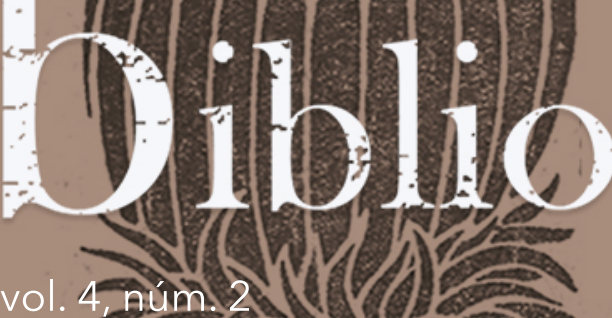

vol. 4, Aum?2

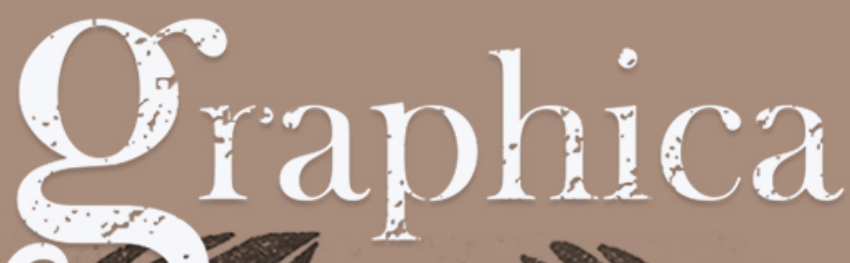

segubdo-semestre 2021 s.

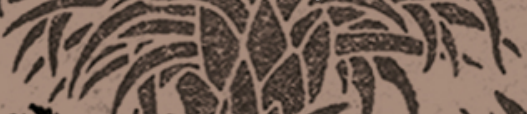
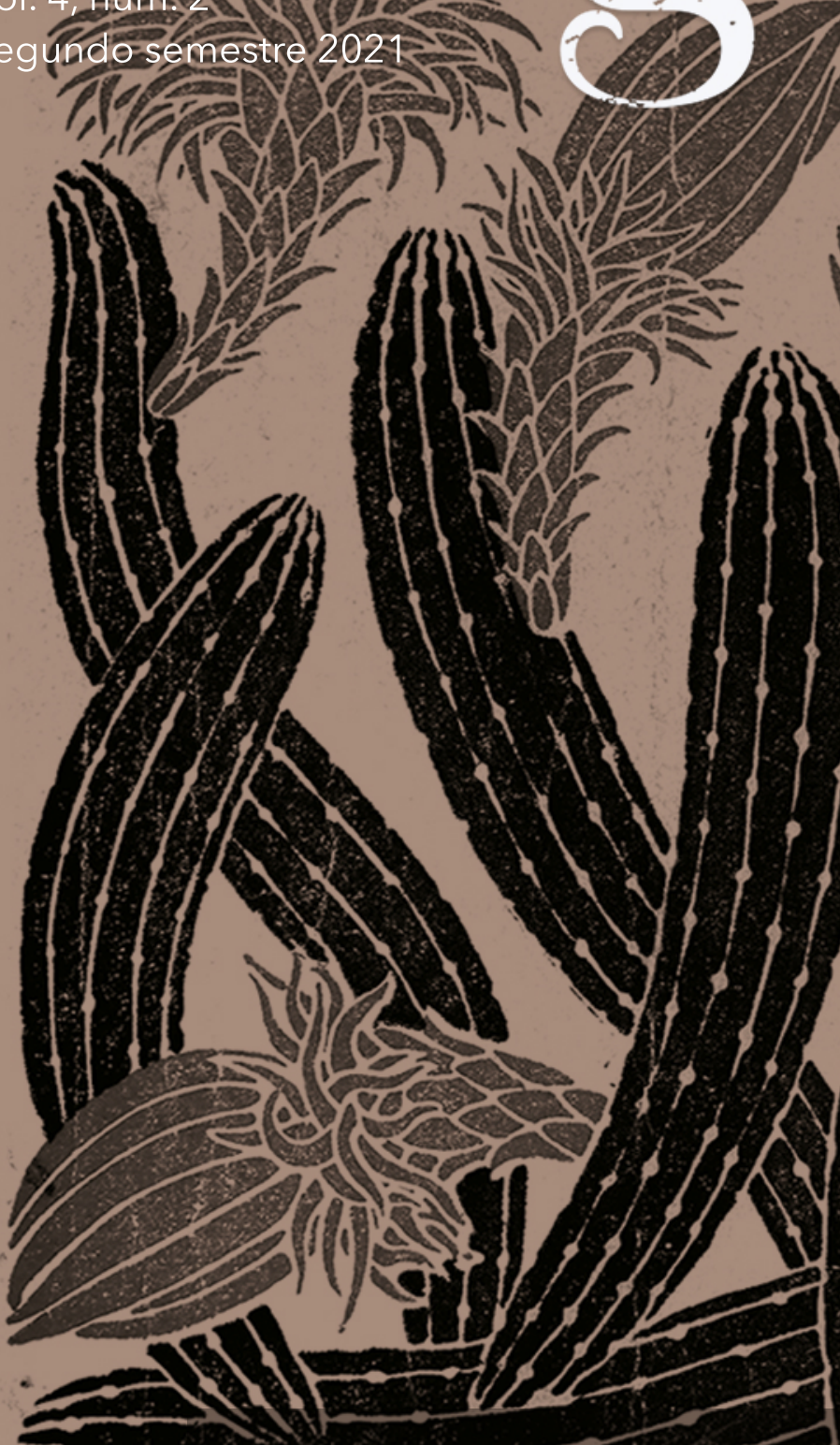

ISSN $2594-178 X$
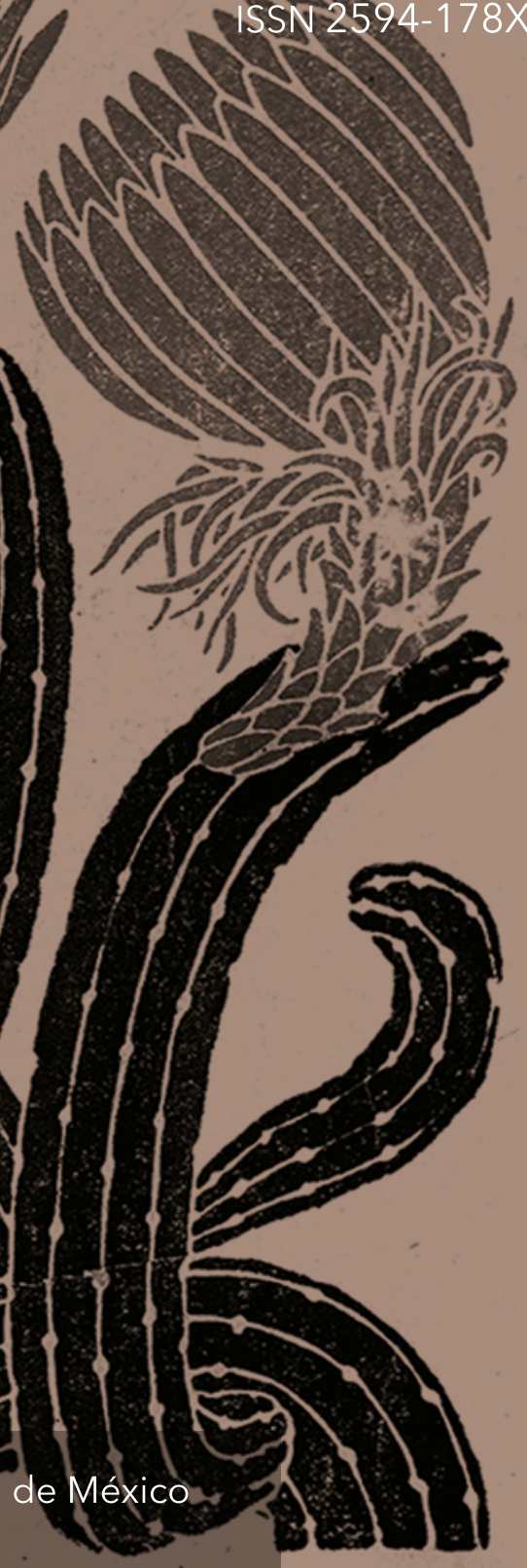


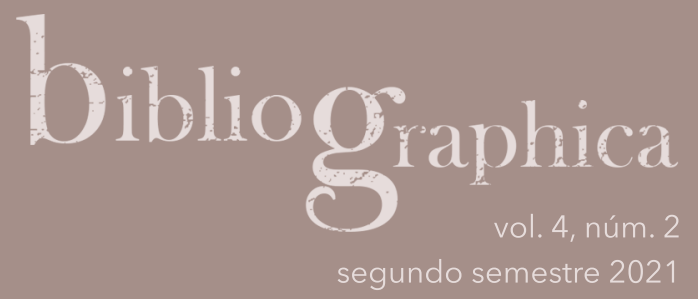

\title{
Grímenes ilustrados: folletín e imaginario visual en la prensa rioplatense, 1846-1880
}

\author{
Illustrated Crimes: Feuilleton and Visual Imaginary \\ in the Rio de la Plata Press, 1846-1880
}

\section{Hernán Pas}

Universidad Nacional de La Plata, Instituto de Investigaciones en Humanidades y Ciencias Sociales, Consejo Nacional de Investigaciones Científicas y Técnicas, La Plata. Argentina hpas@fahce.unlp.edu.ar ORCID: https://orcid.org/000-0003-4365-7662

Recepción: 07.05.2021 / Aceptación: 18.06.2021

DoI: https://doi.org/10.22201/iib.2594178xe.2021.2.121 
Resumen Desde su instalación a mediados de la década de 1840 en Buenos Aires, el folletín se integró perentorio a la prensa rioplatense. Tal integración no resultó pasiva, antes bien generó una serie de fenómenos notables en el precario y emergente mercado del impreso. Por una parte, reconocía y negociaba un horizonte poco o insuficientemente atendido hasta entonces: la cultura del entertainment; por otra, la progresiva "folletinización" de la prensa alcanzó su mayor despliegue con la propagación de imágenes impresas. En efecto, la alianza entre folletín e ilustración generó un tipo de lectura "masiva" que resultó una verdadera novedad en la República de las Letras. Este trabajo procura abordar la historia de esas relaciones, desde el ingreso del género en Buenos Aires (1846) hasta su estilizada culminación con los primeros folletines criollos de Eduardo Gutiérrez publicados en La Patria Argentina (1879-1880).

Palabras clave

Folletín; ilustración; magazine; prensa rioplatense; La Patria Argentina.

Abstract Since its incorporation in Buenos Aires in the mid-1840s, the serial story format (feuilleton) completely integrated to the press sector. Such integration was not passive; on the contrary, it caused several important events in the emergent and precarious printing market. On the one hand, it acknowledged and negotiated with what had not been a sufficiently considered area until then: the entertainment culture; on the other hand, the progressive "serialization" of the press achieved its full development with the propagation of printed images. Furthermore, the alliance between serial works of fiction and illustration generated a popular type of reading that became a true novelty in the Republic of Letters. This paper aims to study the history of these relations, from incorporating the genre in Buenos Aires (1846) to its most artistic form - the serial criollos feuilletons written by Eduardo Gutiérrez and published in La Patria Argentina (1879-1880).

Keywords Feuilleton; illustration; magazine; Rio de la Plata press; La Patria Argentina. 


\section{Introducción}

El 27 de noviembre de 1879, el cráneo del bandido español Antonio Larrea fue expuesto a los lectores de Buenos Aires. El periódico La Patria Argentina, que insertaba en la sección "Variedades Policiales" la biografía de este criminal muerto en la penitenciaría porteña, publicó en su última entrega un estudio frenológico basado en la reproducción del cráneo del delincuente.

Como había ocurrido más de tres décadas antes con la cabeza de Facundo Quiroga -el célebre caudillo biografiado por Domingo Faustino Sarmiento-, la frenología acudía a contener científicamente los desbordes instintivos del amoral, del outlaw. ${ }^{1}$ Pero a diferencia de Sarmiento, Eduardo Gutiérrez -autor de esta biografía, prolegómeno de famosos folletines como el Juan Moreira- no buscaba civilizar con su escritura, sino ofrecer a sus lectores un apoyo empírico, verista, que volviera verosímiles las extravagancias de su biografiado.

Ese afán de verosimilitud se acentuaba, en particular, en La Patria Argentina mediante el recurso de las imágenes. Dos días antes de que los lectores vieran el cráneo estampado (Imagen 2), el rostro del bandido Antonio Larrea se había conocido también en las columnas del mismo periódico (Imagen 1). Para el tipo de lector que diseñaban estos textos -un público lector de periódicos y, más específicamente, de ciertas zonas o secciones del periódico, como las misceláneas o el folletín-, la imagen resultaba tan o más importante que la pericia narrativa con que estaban escritos. ${ }^{2}$

En efecto, cercanas a las litografías de la Revista Criminal, publicación especializada lanzada en 1873, o a las fotolitografías que aparecerían años después en la Galería de Ladrones de la Capital (1887) preparada por José S. Álvarez (Fray Mocho), las imágenes del rostro y del cráneo de Larrea se ubicaban deliberadamente en esa zona ambigua del discurso cientificista, con visos de legalidad, pero al mismo tiempo con un irreprimible afán novelesco.

En consonancia con ello, Máximo Sozzo ha mostrado cómo las estampas litográficas de La Revista Criminal eran esperadas con ansia por el público. Y ha destacado también cómo esas litografías acompañaban la construcción ficcio-

\footnotetext{
${ }^{1}$ La frenología todavía reaparecerá como instrumento narrativo-cientificista en la novela La bolsa de huesos, de Eduardo Holmberg, publicada en 1896.

${ }^{2}$ En otro trabajo procuré describir con mayor detalle este tipo de lectorado, cuyos intereses fueron interpelados, antes que por el libro, por la prensa periódica. Cfr. Hernán Pas, "Eugène Sue en Buenos Aires. Edición, circulación y comercialización del folletín durante el rosismo", Varia Historia 34, núm. 64 (2018): 221-223.
} 
nal de los homo criminalis, algunos de cuyos retratos - como el de "Domingo Parodi, el jorobado, gefe de una gavilla de ladrones"- se convertirían una década después, no casualmente, en materia folletinesca bajo la pluma de Gutiérrez. ${ }^{3}$

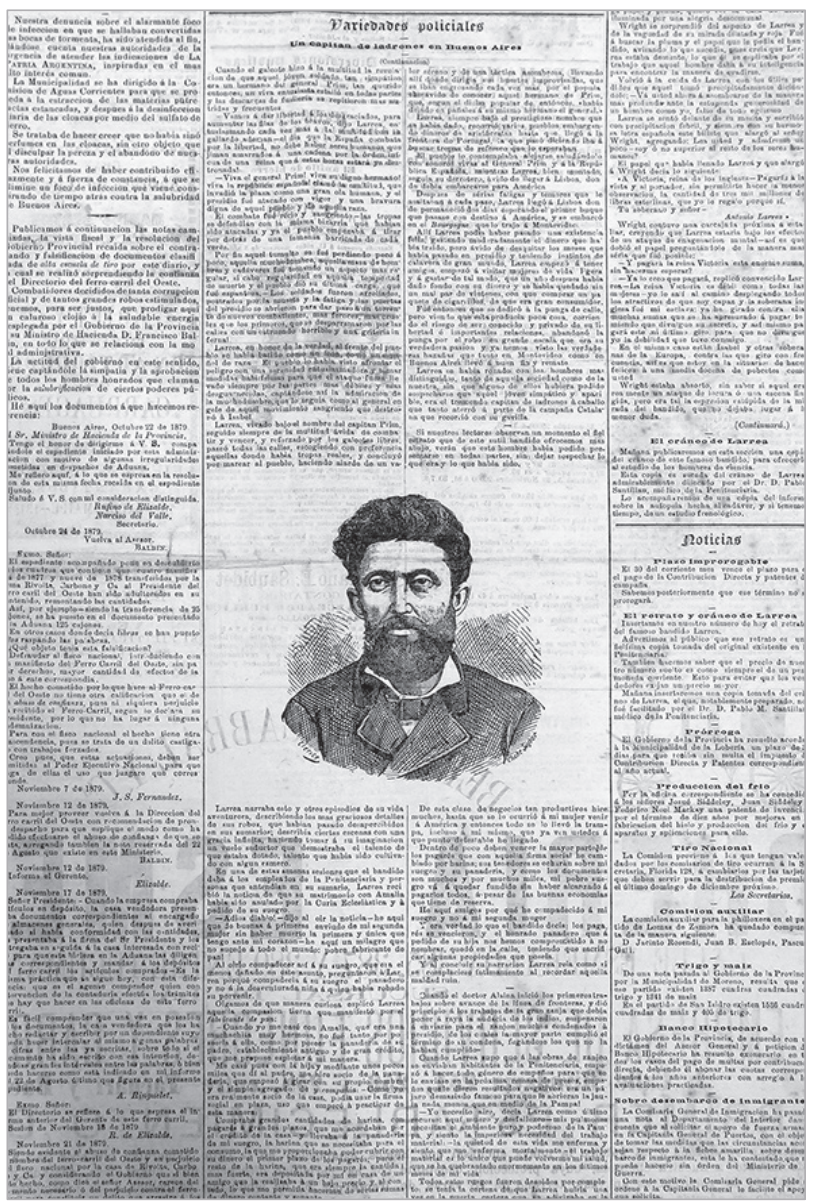

Imagen 1. "Variedades Policiales. Un capitán de ladrones en Buenos Aires", La Patria Argentina, 25 de noviembre de 1879: 1.

\footnotetext{
${ }^{3}$ Máximo Sozzo, "Retratando al 'homo criminalis'. Esencialismo y diferencia en las representaciones 'profanas' del delincuente en la Revista Criminal (Buenos Aires, 1873)", en La ley de los profanos. Delito, justicia y cultura en Buenos Aires (1870-1940), comp. de Lila Caimari (Buenos Aires: FCE, 2007), 23-65.
} 


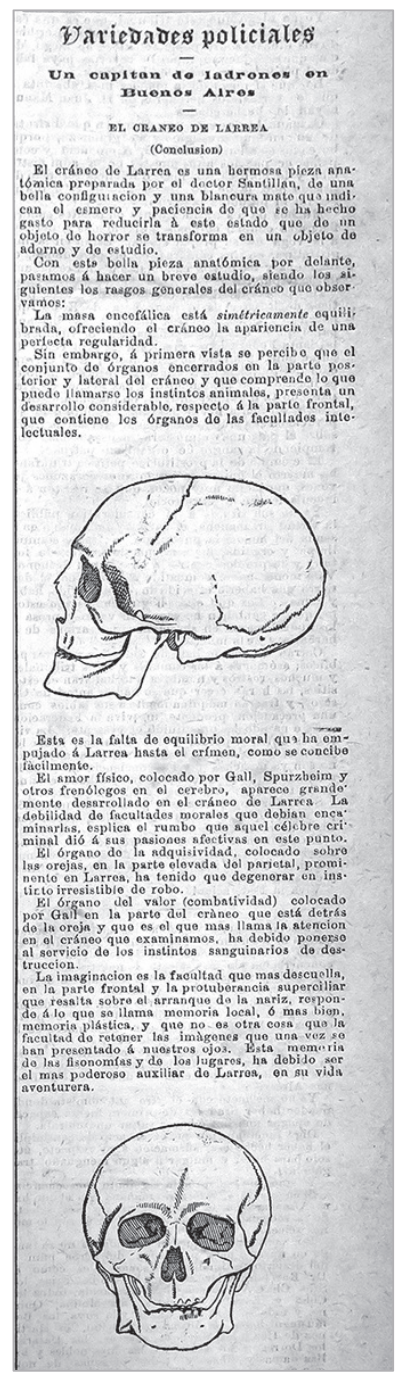

Imagen 2. La Patria Argentina, 27 de noviembre de 1879: 1.

Esa alianza entre imagen y biografía criminal, que se remonta a la tradición de los crímenes célebres -género que, como veremos luego, se hizo popular en manos de Alexandre Dumas- y que está en la base de los folletines gauchescos de Gutiérrez, no era sino el resultado de una larga transformación operada en la prensa periódica en el transcurso de las últimas tres o cuatro décadas. 
El auge del formato magazine y de la literatura folletinesca que se inició a mediados de la década de 1830 en Europa -particularmente en Inglaterra y en Francia- produjo un impacto cultural de resonancias inauditas para la cultura letrada. Los números de ventas de los impresos periódicos -en especial los weekly periodicals londinenses, o la llamada "prensa (de) a 40 francos" parisina, La Presse y Le Siècle- crecieron en muy poco tiempo de manera extraordinaria. ${ }^{4}$

En consecuencia, el público se amplió, el sistema de la prensa se vio transformado y el periódico, en tanto soporte material privilegiado, acaparó las condiciones para la emergencia de lo que Charles Augustin Sainte-Beuve Ilamó, de manera temprana, "literatura industrial". ${ }^{5}$ Si bien en Buenos Aires, y en el Río de la Plata, como en otras ciudades latinoamericanas, las cifras de ventas y de lectores distaban abrumadoramente del canon europeo, lo cierto es que el folletín no sólo se convirtió rápidamente en un ubicuo dispositivo de lectura, acaparando poco a poco el interés del público lector, sino que también transformó las condiciones editoriales de la prensa.

En efecto, el formato coleccionable, introducido por el folletín y la literatura por entregas hacia mediados de siglo, hizo del periódico un objeto nuevo: menos político, más comercial y literario. ${ }^{6}$ Así, los lectores que esperaban ansiosos las entregas de La Revista Criminal -antecedente ineludible al pensar en los lectores de "policiales" de La Patria Argentina- se habían formado presumiblemente leyendo folletines o casos célebres que solían ocupar, como enseguida veremos, páginas enteras -incluso primeras planas- en los periódicos de la época.

${ }^{4}$ The Penny Magazine, precursora en Inglaterra de las ediciones semanales ilustradas, comenzó a publicarse el 10. de marzo de 1832 y en diciembre ya alcanzaba los 200 mil ejemplares de circulación. Patricia Anderson, The Printed Image and the Transformation of Popular Culture 1790-1860 (Oxford: Oxford University Press, 1991), 70-72.

${ }^{5}$ A pesar de tener al folletín como objeto dinamizador, la crítica de Sainte-Beuve estaba dirigida a la prensa: la ley Martignac (1828), al quitar la prebenda estatal, había favorecido el dominio de los avisos comerciales que, en consecuencia, ocuparon el lugar de la crítica cultural. Cfr. Charles A. Sainte-Beuve, "De la littérature industrielle", Revue des Deux Mondes 19 (1839): 682-683.

${ }^{6}$ Me refiero a la tendencia que, con la incorporación perentoria del folletín, se consolida en la prensa periódica de atender la progresiva diversificación lectora. Es un lento movimiento que se inicia con la década de 1830 y que puede constatarse, en el caso del Río de la Plata, por la incorporación de lo "literario" (lo que entonces se llamaba "amena literatura"), incluso en los títulos (encabezados) de los periódicos, que comenzaron a subtitularse, genéricamente, "Político, mercantil y literario" (o alguna fórmula similar). Esto no significa que la prensa se despolitice, sino que lo político empieza, de modo significativo, a convivir con el entertainment. El salto cualitativo en términos de modernización tipográfica se dará en Buenos Aires recién con La Prensa y La Nación, avanzada la década de 1870. 
El folletín había llegado y, en poco tiempo, había promovido nuevas condiciones en la lectura periódica. A partir de entonces, todos los periódicos recurrirían a algún tipo de entrega seriada: o bien mediante el folletín, o con especies de bibliotecas portátiles (formatos coleccionables, en general álbumes, que ocupaban el zócalo del periódico). Esas entregas instalaban una novedosa modalidad de lectura con una parte del impreso (la "literaria"), lectura intensiva y, al mismo tiempo, fraccionada.

\section{Novelas por entregas y folletinización de la prensa. El efecto Sue}

La historia cultural y editorial del folletín ha tenido un amplio abordaje crítico. En los últimos años, por lo demás, una serie de estudios ha venido renovando su enfoque, considerándolo como género o producto de una economía literaria mundial. ${ }^{7}$

A pesar de la inexactitud de considerar al feuilleton un género cerrado -es decir, como roman-feuilleton, novela de folletín-, lo cierto es que con la aparición en 1836 de La Presse, de Émile de Girardin, se dio impulso a la creación de un tipo literario singular. ${ }^{8}$ Entre junio de 1842 y octubre de 1843, Eugène Sue dio a conocer Les mystères de Paris en el Journal des Débats, y un año después comenzó a publicar Le juif errant en Le Constitutionnel; por su parte, Alexandre Dumas, que inauguró con Le capitaine Paul el folletín en Le Siècle, comenzó a publicar en marzo de 1844 en ese mismo periódico Les trois mosquetaires, y en agosto Le comte de Monte-Cristo en el Journal des Débats.

${ }^{7}$ La bibliografía sobre folletín es abundante. Ver, entre otros, René Guise, Le romanfeuilleton 1830-1848: la naissance d'un genre (Lille: A.N.R.T., 1985); Lise Queffélec-Dumasy, Le roman-feuilleton français au XIXe siècle (París: PUF, 1989), y La querelle du roman-feuiIleton. Littérature, presse et politique, un débat précurseur (1836-1848) (Grenoble: ELLUG, 1999); Marlyse Meyer, Folhetim. Uma história (São Paulo: Companhia das Letras, 1996). Marie-Françoise Cachin, Diana Cooper-Richet, Claire Parfait y Jean-Yves Mollier, dirs., Au bonheur du feuilleton. Naissance et mutations d'un genre (États-Unis, Grande-Bretagne, XVIIle-XXe siècles) (París: CREAPHIS Éditions, 2007). Asimismo, sobre los estudios más recientes, mayormente concentrados en el caso Sue, consultar los trabajos enmarcados en el proyecto Les mystères urbains au XIXe siècle: circulations, transferts, appropriations, dirigido por Dominique Kalifa (†) y Marie-Ėve Thérenty (Université de Montpellier), cuyos resultados han sido parcialmente publicados. Acceso el 13 de enero de 2021, www.me dias19.org.

${ }^{8}$ Marie-Ėve Thérenty y Alain Vaillant, 1836: I'an I de l'ère médiatique. Étude littéraire et historique du journal La Presse d'Émile de Girardin (París: Nouveau Monde Éditions, 2001). 
El éxito, como sabemos, fue rotundo. ${ }^{9}$ La obra de Sue, en particular sus Les mystères de Paris, alcanzó rápidamente -en el entramado novedoso provisto por la técnica del folletín y la expansión del mercado del impreso- el valor de caso paradigmático.

Las descripciones de los bajos fondos parisinos, las tabernas y arquitecturas góticas que ensombrecen el paisaje urbano hasta convertirlo en un laberinto de covachas, los personajes característicos de ese submundo criminal y marginal, como el famoso churriador o cuchillero (chourineur, del argot franco chouriner), más que el típico maniqueísmo abstracto de corte melodramático y el suspenso narrativo de sucesos, fue quizá lo que impulsó el éxito mundial de Los misterios de París.

La novela de Sue proponía al lector ingresar a ese submundo por el último peldaño de la escala social: la sugestión del contraste, en este caso, reforzaba la curiosidad del voyeur. ${ }^{10}$ Se trataba, en todo caso, de resaltar -con la misma técnica del tableaux que se utilizaba para los tipos exóticos de regiones remotasun sector social que, salvo como decorado o trasfondo, nunca había aparecido con esa intensidad en las descripciones que ofrecía la literatura. Lo paradójico es que este modelo, que había invertido la visión exotista de Fenimore Cooper -los "bárbaros", "les sauvages peuplades si bien peintes par Cooper", no debían buscarse en tierras lejanas, sino que ahora estaban entre los lectores-, nutrió

9 Para tomar dimensión del asunto, veamos un solo ejemplo: el periódico francés Le Constitutionnel tenía (en marzo de 1843) 3428 suscriptores; aumentó esa cifra a 16 mil en agosto de 1844, y trepó a 25 mil suscriptores en enero de 1845. El gran aumento de las ventas coincidió con la publicación por entregas de El judío errante, de Eugène Sue: del 25 de junio de 1844 al 26 de agosto de 1845. Cfr. Maria Adamowicz-Hariasz, "From the Opinion to the Information: The Roman-Feuilleton and the Transformation of the Nineteenth-Century Fench Press", en Making the News. Modernity \& the Mass Press in Nineteenth-Century France, ed. de Dean de la Motte y Jeannene M. Przyblyski (Amherst: University of Massachusetts Press, 1999), 167-168.

${ }^{10}$ En los párrafos introductorios a la primera entrega del folletín, había escrito Sue: "Sin la imperiosa exigencia de la narración, lamentaríamos el haber colocado en tan horrendo lugar la exposición del relato que se va a leer. Sin embargo, confiamos un poco en esa especie de curiosidad asustadiza que a veces incitan los espectáculos terribles". Y, más adelante: "El lector, prevenido de la excursión que le proponemos emprender entre los naturales de esta raza infernal que puebla las cárceles, los presidios, y cuya sangre enrojece los patíbulos... el lector podrá seguir con nosotros. Sin duda esta investigación será nueva para él; nos apresuramos en advertirle que, si desde el inicio posa el pie en el último escalón de la escala social, a medida que el relato avance, la atmósfera se purificará cada vez más", Journal des Débats, 19 de junio de 1842: 1, col. 2. Traducción del autor. 
una larga serie de apropiaciones caracterizada, en su mayor parte, por una notable disonancia con el objeto geográfico y social de esa narrativa criminal. ${ }^{11}$

Al mismo tiempo, como dejan ver los mediadores y receptores de esa onda expansiva, había un núcleo temático -los bajos fondos, los personajes marginales- que acompañaba a la expansión capitalista, esto es: parte del éxito de Los misterios de París residía en la potencial universalización de sus tópicos. Este aspecto era evidenciado, por ejemplo, en la traducción barcelonesa de la novela, cuya introducción destacaba la similitud del lenguaje patibulario:

La conveniencia de sustituir al argot francés el caló español o la germanía, a fin de presentar en su luz algunos de los principales caracteres de la obra, nos parece tan evidente que nos abstenemos de insistir en ella. Esta persuasión nos ha obligado a formar un copioso vocabulario del horrible idioma de los presidios y de las gavillas de ladrones; ímprobo y enojoso trabajo en el cual nos ha llamado la atención la similitud general y la frecuente identidad de los signos del lenguaje de los malhechores en ambos países. ${ }^{12}$

Trabajo similar al del etnólogo, el traductor observa las diferencias y similitudes culturales. Ahora bien: si el idioma de los presidios amerita un vocabulario, la gramática delictiva, en cambio, se muestra universal. Una narrativa universal del crimen, cada vez más estandarizada, cuya materia podía cumplir con la doble función de entretener y moralizar, comienza a expandirse a mediados de la década de $1840 .{ }^{13}$ En ella, los nombres de Sue y Dumas (y luego Ponson du

11 "Chaque ville se veut Paris pour le mystère", escribió Bory. Hubo hasta misterios húngaros: Mystères hongrois, de Ignace Nagy. Cfr. Jean-Louis Bory, Eugène Sue, le roi du roman populaire (París: Hachette, 1962), 288-290. En su amplia circulación, la afamada novela de Sue fue modelada de acuerdo a intereses propios de los mediadores-receptores. Las ediciones ilustradas mexicanas, por ejemplo, buscaron moralizar mediante tipos (tomados de la edición de Gosselin), evitando la reproducción de espacios sórdidos o de escenas violentas. Ver, al respecto, el trabajo de Ma. Esther Pérez Salas, "Las imágenes de Los misterios de París en las ediciones mexicanas", en Tras las huellas de Eugenio Sue. Lectura, circulación y apropiación de Los misterios de París. Siglo XIX, coord. y ed. de Laura Suárez de la Torre (México: Instituto Mora, 2015), 184-196. Ver, asimismo, el citado dossier Kalifa y Thérenty, Les mystères urbains au XIXe siècle: circulations, transferts, appropriations, www.medias19.org.

${ }^{12}$ Eugène Sue, Los misterios de París, edición adornada de cien láminas, traducción de D. A. X. San Martin (Barcelona: Imprenta de Saurí, 1845), ix.

${ }^{13}$ En Francia, esa narrativa tendría un impulso decisivo a partir de Le Petit Journal (1863). Los relatos criminales funcionaban, según Kalifa: "comme une sorte de catalyseur des inquiétudes de opinion et des dysfonctionnements sociaux". Dominique Kalifa, "Usages du 
Terrail) funcionan como marcas: basta evocar una de esas firmas para atraer al lector y garantizar su compromiso.

En Buenos Aires, los textos de Sue y Dumas ingresaron a través del Correo de Ultramar, diario mensual producido y editado en París para un amplio público hispano que incluía, de modo estratégico, las distintas cabeceras americanas de los antiguos virreinatos - desde México hasta Buenos Aires y Montevideo-. Entre febrero de 1845 y marzo de 1846, una larga serie de avisos publicitarios colocaron la novelas de Dumas y Sue al alcance de los lectores bonaerenses, y junto con la proliferación de ediciones locales (piratas) apareció el primer folletín en la prensa local: el 16 de marzo de 1846, el Diario de la Tarde comenzó a ofrecer en su zócalo nada menos que El judío errante, de Sue. ${ }^{14}$

En términos editoriales, la repercusión fue tal que, como había ocurrido en otras ciudades del mundo, no hubo desde entonces periódico -serio, satírico, ilustrado, comercial, diario, hebdomadario o mensual- que no incluyera un folletín en la parte inferior de su primera página. Los avisos se multiplicaron, y con el correr de los años hubo también en el Río de la Plata versiones especulares de los Misterios parisinos. ${ }^{15}$

Junto con la difusión de las novelas de Sue y Dumas, se instaló en la prensa rioplatense, de modo perentorio, el formato del folletín, que rápidamente se convirtió en una sección fija. Esa omnipresencia del folletín, garantía cada vez más acentuada de una virtual suscripción sostenida, no pasó desapercibida a los letrados y publicistas criollos de la época. Pocos años después, en abril de 1852 -es decir, a escasos meses de la célebre batalla de Caseros, que terminaría con el régimen rosista-, Bartolomé Mitre fundaría el periódico Los Debates. En su primer editorial -bastante recordado, titulado "Profesión de fe"- Mitre quiso subrayar que la discusión pública se erigiría desde entonces como la mejor con-

faux. Faits divers et romans criminels au XIXe siècle", Annales. Histoire, Sciences Sociales, año 54, núm. 6 (1999): 1355.

${ }^{14}$ La entrada de las novelas de Sue (y también de Dumas) en Buenos Aires se dio, al igual que en México y otras ciudades latinoamericanas, a través de El Correo de Ultramar, que intermedió las entregas de los títulos más célebres. Sobre el tema, me he explayado en otro trabajo. Hernán Pas, "Eugène Sue en Buenos Aires..." Sobre el caso mexicano, ver Laura Suárez de la Torre, "Lecturas y lectores de misterios en la Ciudad de México, siglo XIX", en Tras las huellas de Eugenio Sue..., 138-159.

${ }^{15}$ En el periódico carioca O Jornal das Senhoras su redactora, la escritora exiliada argentina Juana Manso, dio a conocer Los misterios del Plata, y en 1856 aparecieron en La Tribuna de los Varela, periódico al que volveremos, Los misterios de Buenos Aires, novela escrita por Felisberto Pélissot, un emigrado francés radicado en la provincia de Tucumán. 
tracara de una sombría época de uniformidad en la opinión. Pero tanto o más importante que esa declaración (al fin y al cabo, un tópico entre los publicistas de la época), resultaba su atención al folletín: "Hasta hoy ningún periódico americano ha dado a esta parte del diario [el folletín] su carta de ciudadanía: ella no se adorna sino con pensamientos extraños naturalizados por los tipos de imprenta; y sin embargo esa es la parte del Diario que busca con más placer la mayoría de los lectores, ¿por qué no nacionalizarla?".

Al reconocerla como la sección más leída, Mitre daba al mismo tiempo una definición que la distinguía temáticamente del resto del periódico, colocando al folletín en la zona del ocio: "El folletín en los periódicos modernos es como esos bajos relieves que corren graciosamente al pie de las columnatas dóricas. Lo mismo que en las obras del artista, el pensamiento serio del escritor se refugia en la forma severa de la columna; los caprichos tienen su lugar en el friso esculpido cuidadosamente en los ratos de ocio". ${ }^{16}$

La jerarquización entre lecturas serias y lecturas ociosas tenía como subtexto la breve historia del género, aunque se extendería, como sabemos, a lo largo del siglo, y aun más allá. ${ }^{17}$ Durante poco más de una década, los nombres de Eugène Sue y Alexandre Dumas plagaron las entregas en los zócalos de los periódicos rioplatenses.

En El Nacional -continuación del Diario de la Tarde-y La Tribuna, dos publicaciones periódicas dominantes en Buenos Aires durante varios lustros luego de la caída de Rosas, comenzarían a sucederle a esos nombres los de Émile de Girardin, Wenceslao Ayguals de Izco, Pérez Escrich, Ponson du Terrail, Manuel Fernández y González.

El reclamo de Mitre por nacionalizar esa sección (la más leída) del diario, si bien tuvo eco intermitente, no hallaría su verdadera contraparte sino casi tres décadas más tarde, cuando Eduardo Gutiérrez comenzara a publicar en La Patria Argentina su saga de novelas gauchescas.

\footnotetext{
${ }^{16}$ Bartolomé Mitre, "Folletín", Los Debates, núm. 1 (10. de abril de 1852): 2. Los Debates era continuación del Agente Comercial del Plata (que había comenzado a publicarse en 1851) y éste, en su corta vida, venía publicando algunos folletines extranjeros (Alexandre Dumas, Pexier D'Arnoult).

${ }^{17}$ Thérenty ha analizado la dinámica de esa bifurcación (el arriba y el abajo) del periódico decimonónico, planteando la preeminencia de un "discurso social ficcionalizante": los escritores-periodistas creaban géneros de información que recurrían a una matriz literaria, contaminando la superficie retórico-discursiva de la prensa. Marie-Ėve Thérenty, "El folletín en los periódicos del siglo XIX: ¿hecho literario o fenómeno social?", en La invención de la cultura mediática.Prensa, literatura y sociedad en Francia en el siglo XIX (México: Instituto Mora, 2013), 11-29.
} 
No obstante, el dispositivo folletín se había instalado en la prensa de modo categórico, como muestra la cita de Mitre, acaparando la atención no sólo de los lectores, sino también de los redactores y editores. Tal impacto causó entre los lectores e impresores que, ante la novedad, la prensa incluso llegó a pergeñar la figura del "folletinista".

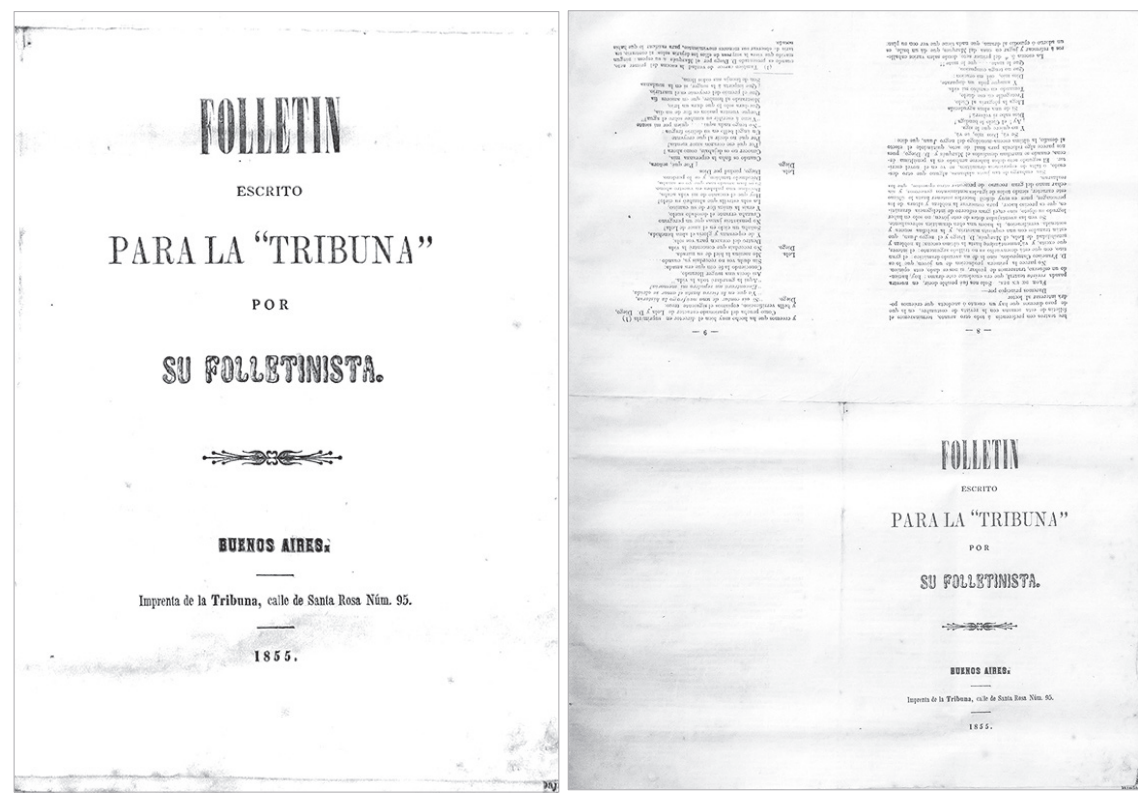

Imágenes 3 y 3a. La Tribuna, 8 y 9 de enero de 1855.

Folletín en formato coleccionable, tirada aparte.

Como el cronista, el folletinista era, al parecer, un causer con la pluma en la mano, según la definición de "chroniquer" que daría un importante periódico francés de la época. ${ }^{18}$ Una protofigura del cronista urbano, o del flâneur-escritor, que combinaba apreciaciones de tinte costumbrista con algo de actualidad y chismografía comarcana.

18 "Selon Jouvin, 'chroniquer, c'est causer la plume à la main' ('Messieurs les chroniqueurs', Figaro, 22 février 1866)". José-Luis Díaz, "Avatars journalistiques de l'éloquence privée", en La civilisation du journal. Histoire culturelle et littéraire de la presse française au XIXe siècle, dir. de Dominique Kalifa, Philippe Régnier, Marie-Ėve Thérenty y Alain Vaillant (París: Nouveau Monde Éditions, 2011), 708-709. 
En 1855 el diario La Tribuna tuvo su folletinista, figura un tanto fugaz, aunque de importante espacio en el periódico. En entrega separada, con formato de colección, el folletinista declaraba: "A buen seguro que yo no llenaría mi misión de Folletinista, si a modo de ave volátil no me transportase de un punto a otro de esta hermosa ciudad y aun de sus campiñas, para poder narrar todo cuanto veo, oigo, y aun cuanto palpo". ${ }^{19}$

A modo de las fantasías ópticas del excursionista y explorador, el ave volátil -con ímpetu panóptico- es aquí un narrador urbano. Síntoma de época, el fragmento citado permite captar el pasaje de una prensa doctrinaria, incluso facciosa, a un tipo de escritura cuyo fundamento reside en el gusto de un público que excede -que ya comienza a exceder- a aquel que transita (o transitaba) el periódico como si de un ágora impreso se tratara.

\section{Magazine y lectura. La potencia de las imágenes}

Por su estilo hiperbólico y descriptivo, por su inclinación tópica y sensacionalista, el folletín nació para ser ilustrado. Buena parte de las novelas publicadas en esa sección de los diarios pasó luego a una edición por entregas, siempre ilustradas. Lo que, por cuestiones de costos y técnicas materiales adecuadas, los periódicos no estaban en condiciones de hacer aún, es decir publicar en sus páginas inferiores novelas ilustradas, lo hacía en cambio la palestra editorial mediante novelas publicadas por suscripción, universo embrionario (y ciertamente expansivo) de popularización de la lectura.

En ese marco editorial, uno de los cambios notables que introdujo la llamada penny press (Schudson) fue la decisiva integración de las imágenes al espacio tipográfico del periódico. En efecto, si bien las imágenes, en forma de viñetas o dibujos, habían acompañado desde siempre la cultura impresa, el desarrollo de nuevas técnicas de reproducción pictórica, como fue el caso de la litografía, produjo una evolución marcada y constante de las tecnologías reproductoras de la imagen, ampliando cada vez más el conjunto de posibilidades: el grabado en madera de boj, la cromolitografía (creada en Francia a mediados de 1830), y posteriormente la fotografía y el fotograbado. ${ }^{20}$

\footnotetext{
${ }^{19}$ La Tribuna, 8 y 9 de enero de 1855: 1.

${ }^{20}$ La litografía fue un hallazgo del dramaturgo bávaro Alois Senefelder quien, hacia finales de 1790, estando escaso de recursos para hacer imprimir sus propios escritos, ideó un modo más expeditivo y económico que el del impreso tipográfico tradicional: la técnica de impresión litográfica. En Latinoamérica, sería la técnica de reproducción de imágenes
} 
El progresivo uso de la técnica litográfica trajo consigo un cambio sustantivo en los modos de percibir, leer y consumir impresos, posibilitando, entre otras cosas, la presencia cada vez mayor de estampas en las tiradas cotidianas. En ese marco, valiosos estudios como los de Patricia Anderson (1993), Brian Maidment (2001) o Laurel Brake y Marysa Demoor (2009) han descrito detalladamente el auge y la expansión del nuevo formato ilustrado, el magazine, definido por la prensa contemporánea como "an illustrated newspaper". ${ }^{21}$

El dominio del weekly ilustrado, que en Londres comenzó con la aparición de The Penny Magazine, en 1832, editada por Charles Knight y la Society for the Diffusion of Useful Knowledge, y en Francia tuvo su expresión homóloga con el Magasin Pittoresque de 1833, supuso no sólo una ampliación de los públicos lectores, sino también la emergencia de un tipo de prensa de carácter misceláneo, cuya consolidación y expansión se debió, en buena medida, a la alianza que estableció con los relatos seriados. ${ }^{22}$

En Buenos Aires, los primeros ensayos en ese sentido fueron los semanarios ilustrados Museo Americano (1835) y El Recopilador (1836) de César Hipólito Bacle, publicados a mediados de la década de 1830, que buscaron captar el interés lector mediante la novedad de imágenes estampadas acompañando cada entrega. ${ }^{23}$ No obstante, la iniciativa no perduró, y fue recién con la aparición en 1864 del Correo del Domingo cuando la combinación entre texto e imagen alcanzó una primera estilización editorial en la prensa periódica bonaerense.

más desarrollada y utilizada. Cfr. Hernán Pas, "La seducción de las imágenes. El ingreso de la litografía y los nuevos modos de publicidad en Latinoamérica", Caracol, núm. 2 (2011): 10-41.

21 "Preface", Illustrated London News (1843), tomado de Laurel Brake y Marysa Demoor, eds., The Lure of Illustration in the Nineteenth Century. Picture and Press (Londres; Nueva York: Palgrave MacMillan, 2009), 4.

22 Patricia Anderson señala que el universo de la imagen debía ser analizado junto con los avisos (advertisements), que empezaron a constituirse en pequeñas viñetas o dibujos autónomos dentro del periódico, y con las novelas seriadas ("sold in penny parts"), que fagocitaron el interés del nuevo público lector (las más populares en Londres fueron Uncle Tom's Cabin, de Harriet Beecher Stowe, y The Mysteries of London, de George W. Reynolds). Cfr. Anderson, The Printed Image, 196-198.

${ }^{23}$ De hecho, varias de las ilustraciones de estos semanarios fueron reproducciones tomadas de The Penny Magazine y The Magasin Pittoresque. Ver, al respecto, el trabajo de María Lía Munilla Lacasa y Georgina G. Gluzman, "Imágenes globales/selecciones locales: las publicaciones periódicas europeas en los diarios porteños. El caso de El Recopilador y Andrea Macaire", en llustrar e imprimir. Una historia de la cultura gráfica en Buenos Aires 1830-1930, coord. de Sandra Szir (Buenos Aires: Ampersand, 2016), 23-52. 


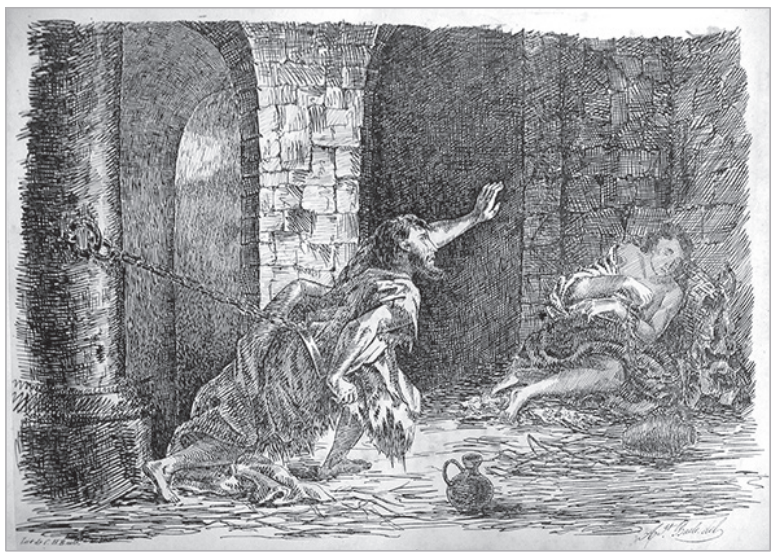

Imagen 4. "El preso de Chillon", El Recopilador, núm. 5 (1836). Reproducido de Le Magasin Pittoresque, núm. 10 (1835).

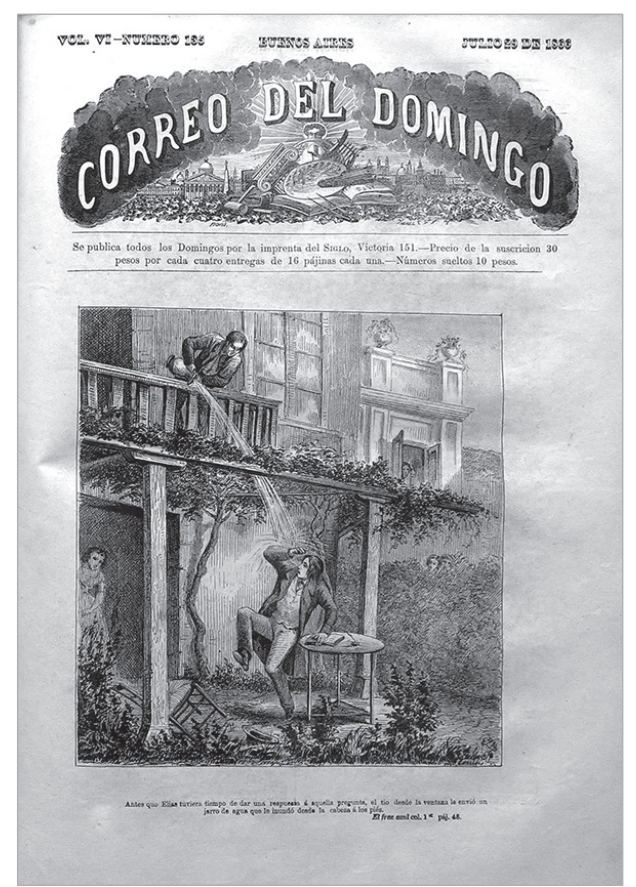

Imagen 5. Ilustración de la novela de Pérez Escrich, Correo del Domingo, núm. 135 (1866). 
Un año antes había aparecido El Mosquito, célebre publicación satírica e ilustrada de larga trayectoria. Pero mientras que El Mosquito destinaba sus imágenes a intervenir en la cotidianidad política y cultural, el Correo del Domingo fue la primera publicación "magazinesca" que procuró conjugar el sistema de las novelas ilustradas por entregas con la edición periódica, como muestran las estampas que acompañan las novelas El asesino de Albertina Renouf, de Henrique Riviére, y El frac azul, de Enrique Pérez Escrich (Imágenes 5-7). ${ }^{24}$

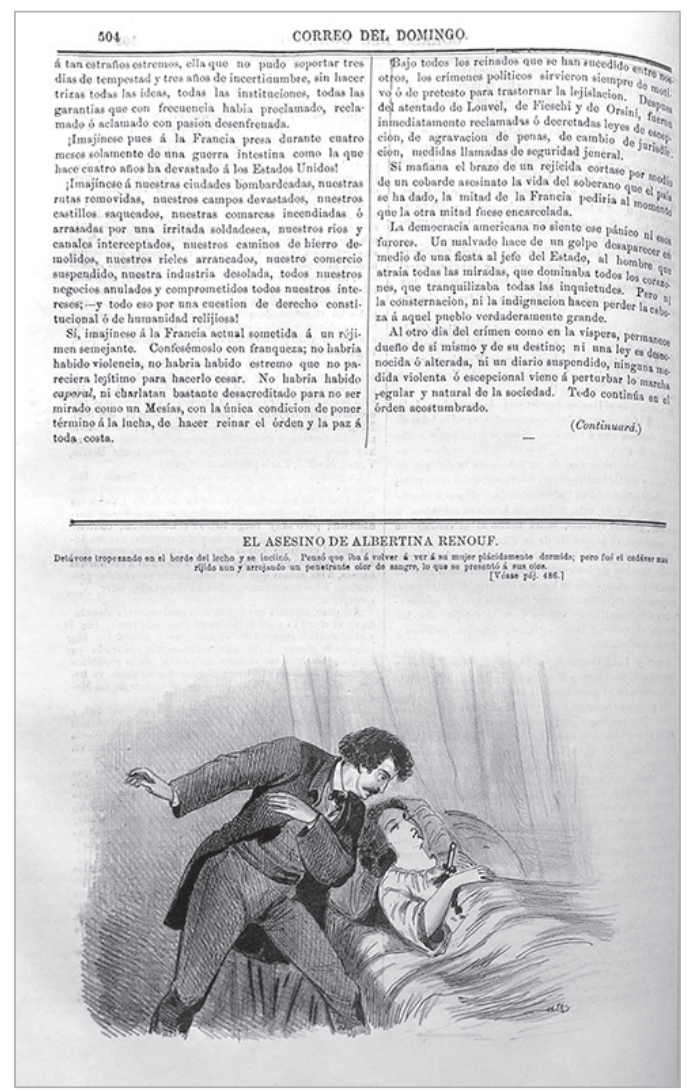

Imagen 6. Ilustración de la novela de Riviére, Correo del Domingo, núm. 83 (1865).

\footnotetext{
${ }^{24}$ Sobre El Mosquito, consultar Claudia Roman, Prensa, política y cultura visual. El Mosquito (Buenos Aires, 1863-1893) (Buenos Aires: Ampersand, 2017).
} 


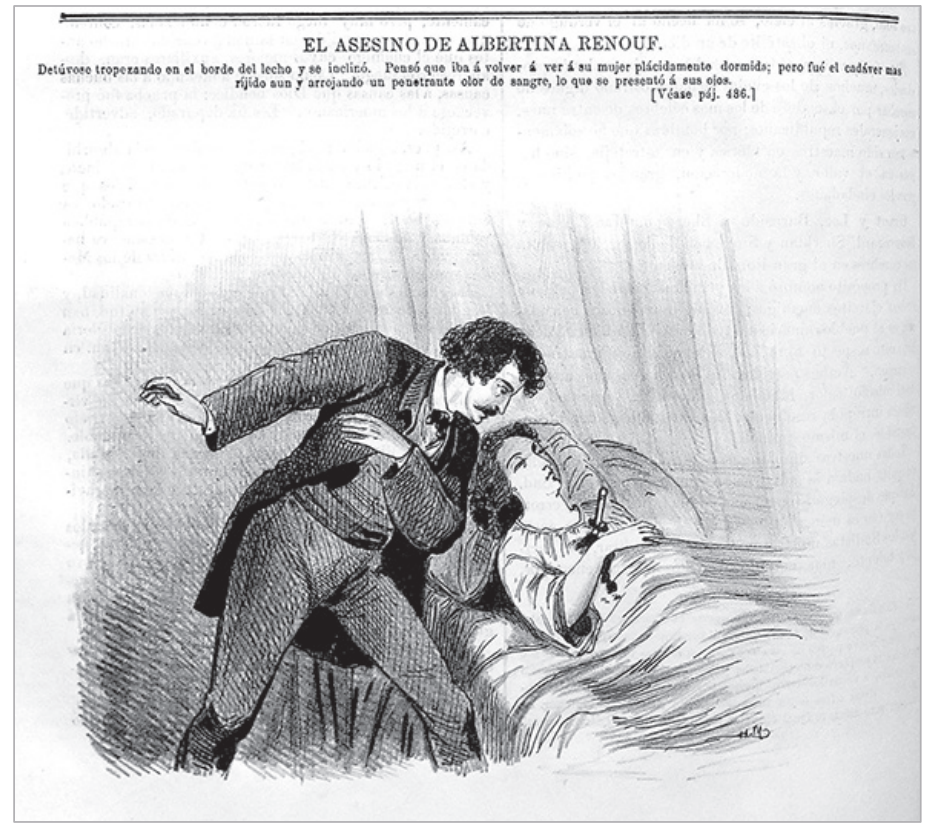

Imagen 7. Ilustración de la novela de Riviére. Ampliación.

Leyenda: "Detúvose tropezándose en el borde del lecho y se inclinó.

Pensó que iba a volver a ver a su mujer plácidamente dormida;

pero fue el cadáver más rígido aún y arrojando un penetrante olor de sangre,

lo que se presentó a sus ojos".

Si bien la mayoría de las ilustraciones del Correo del Domingo poseía un carácter más bien biográfico o enciclopédico, estas imágenes narrativas resultaban sintomáticas de una vertiente editorial que empezaba a imponerse. En este sentido, la escena representada de la novela El asesino de Albertina Renouf, el momento en que el protagonista halla a su esposa apuñalada en su lecho, remite a una larga tradición folletinesca centrada en el crimen, que ya hemos mencionado: la de las causas célebres.

El antecedente más destacado de este tipo de historias se remonta a mediados del siglo XVIII. Entre 1734 y 1743 aparecieron en 20 volúmenes las Causes célèbres et intéressantes recuillés par Gayot de Pitaval. ${ }^{25}$ Cabe recordar

${ }^{25}$ Un umbral más lejano fueron las Histoires mémorables et tragiques de ces temps (1614), de François Rosset. 
que de esa compilación extrajo Alexandre Dumas los perfiles biográficos y las historias de sus Crimes célèbres, 18 textos publicados en París en ocho tomos, entre 1839 y 1840, cuya circulación alcanzó varias ciudades de Latinoamérica.

Además del sentido formativo que tuvo para el propio Dumas esa transposición, los Crimes célèbres se convirtieron en una pequeña biblioteca de macabras historias sangrientas, a mano de escritores y folletinistas que empezaban a consolidar el género en la prensa.

Basta observar los principales periódicos de Buenos Aires de mediados del siglo para corroborar la presencia frecuente de este tipo de textos (que en general, además, ocupaban una superficie importante de las primeras páginas). Por cierto, los exhortos de las causas penales del rosismo resultaban más que oportunos para dicha retórica. En 1853, El Nacional publicaba el juicio seguido a Ciriaco Cuitiño y Leandro Alen, dos de los vigilantes de la policía rosista e integrantes de la "mashorca", por los crímenes cometidos en 1840 y 1842; poco después, en 1855, La Tribuna ofrecía en su zócalo el folletín "Un episodio del año 40 en Buenos Aires", el cual, como tantas otras textualizaciones conocidas, narraba la historia de un amor (de unitarios) cercenada cruelmente por la banda parapolicial de Rosas (representada por un tal don Fernando, emblema de jefe policial a lo Cuitiño). ${ }^{26}$

Pero si los crímenes rosistas se avenían previsibles al género, lo cierto es que, como ocurría con los folletines, en la prensa prevalecía una gramática del terror, gramática delictiva que respondía a su vez a un formato universal, estandarizado. De este modo, las llamadas "causas célebres" se reproducían como relatos seriados, desatendiendo la distancia cultural o territorial que suponía tal reproducción. Así, en 1864, La Tribuna hacía eco del caso del médico ho-

${ }^{26}$ El folletín, endeble desde todo punto de vista, cuenta una historia de amor entre Julia, a quien se describe como "una hermosa rubia, muy blanca", y el moreno Alfredo (contraste que es debidamente resaltado). Don Fernando, jefe de mazorqueros, enamorado de Julia, decide secuestrar y encerrar en un calabozo a Alfredo, pasándolo por muerto (cfr. La Tribuna, núms. 633-635, 13-16 de octubre de 1855). La novelita se inserta en el contexto de una producción de propaganda antirrosista que incluye, en la misma línea, títulos como "Dos víctimas de 1840", de José Víctor Rocha (La Tribuna, 20-22 de abril de 1857); "Carlota - Una víctima de la mas-horca", de Francisco López Torres (una sola entrega en La Tribuna, 12-13 de enero de 1857); o la saga de novelas que van desde Amalia (1855, Imprenta Americana), de José Mármol, y la citada Los misterios del Plata, de Juana Manso, hasta Camila O'Gorman (1856, Imprenta Americana), al igual que la serie de relatos de Gorriti: El guante negro, El lucero del Manantial, La hija del mashorquero (1860-1863). 
meópata Edmond-Désiré Couty de la Poummerais, acusado de envenenamiento, que había mantenido en vilo a la sociedad francesa, condenado a muerte el 5 de junio de ese mismo año. ${ }^{27}$

Muchas de las causas tenían ilustres linajes, por ello también resultaban, en parte, célebres. Es el caso del médico francés. En efecto, la causa del homeópata Couty de la Poummerais se inscribía en una larga serie de crímenes por envenenamiento, serie que se extendía desde la antigüedad grecorromana hasta el resonante caso parisino en 1840 de Madame Lafarge, que daría comienzo a la toxicología como rama forense, pasando por los Borgia y los Médici en el Renacimiento. ${ }^{28}$

De hecho, entre la saga de los célebres asesinatos reescrita por Dumas, además de la historia de los Borgia, que ocupa el lugar decimosegundo, el futuro autor de El conde de Montecristo reescribe la historia de "La Marquesa de Brinvilliers (1676)", que cuenta precisamente cómo esta marquesa, María Magdalena, se confabula con su amante, Gaudin de la Croix, para asesinar a sus parientes (empezando por su padre) recurriendo al veneno. Y no es casual que Dumas haga ingresar en la historia a un experto en envenenamiento italiano, Exili, famoso por el uso de pócimas y venenos, quien se encarga de transmitir sus conocimientos a De la Croix.

Pocos meses antes de publicar el caso del médico homeópata francés, el mismo diario La Tribuna ofrecía, junto al infaltable folletín, una seguidilla de

${ }^{27}$ Distancia, también, cronológica. Las audiencias del caso Poummerais se llevaron a cabo del 9 al 16 de mayo de 1864. Los más importantes diarios parisinos (La Presse, Le Petit Journal, Les Temps, Le Constitutionnel) reprodujeron el juicio durante los días subsiguientes. El texto de La Tribuna, previsiblemente traducción de alguna de las entregas de los periódicos franceses, comenzaba afirmando: "El 9 de este mes, el tribunal de Assises del Sena abrió los debates para fallar la causa instruida contra M. Couty de la Pommerais, médico homeópata, y que desde luego no vacilamos en clasificar como una causa célebre", 21 de julio de 1864: 1. Para el lector porteño desprevenido, a quien no socorría ninguna referencia, "El 9 de este mes" resultaba sin dudas un dato cronológico ambiguo (¡de qué mes: julio, junio, mayo!).

${ }^{28}$ El comienzo de la ciencia toxicológica data de 1840. En septiembre de ese año se juzgó a Marie Lafarge, acusada de haber asesinado a su marido sirviéndole arsénico en la comida y en la bebida. En el caso intervino el doctor Mateu Orfila (de origen español, y radicado en París desde hacía varios años), quien aplicó el "test de Marsh" y encontró arsénico metálico en todos los órganos de Lafarge. Con la prueba científica, Marie fue declarada culpable. Por primera vez en la historia se condenó a alguien gracias a la ciencia toxicológica. El doctor Orfila propició la introducción del análisis toxicológico como prueba científica y por ello se ganó el apodo de "padre" de la toxicología forense. 
relatos misceláneos, cuyos títulos resultaban por demás sugerentes: "El crimen castigado" (6 de marzo de 1864), "La sombra ensangrentada" (14-15 de marzo de 1864), "Si haces mal no esperes bien" (3 de julio de 1864) y otros relatos semejantes cubrieron las primeras páginas durante varios días, entre marzo y julio de $1864 .^{29}$

Leer un periódico en Buenos Aires en 1860, o la primera página de un periódico en la Buenos Aires de 1860, podía parecerse a leer una miscelánea por entregas, en la que nunca, o casi nunca, faltaba el crimen.

\section{Crímenes (criollos) ilustrados}

Las causas célebres llegaron a convertirse en una sección recurrente de la prensa periódica hacia finales de siglo. Su progresiva transición hacia los casos locales favoreció la construcción de un discurso verista, que sin embargo pivoteaba con la zona de lo increíble, de lo morboso, de lo extraordinario. Como resultado de ello, comenzaba a ser cada vez más habitual la contaminación entre las crónicas periodísticas y las pesquisas policiales. ${ }^{30}$

29 Los relatos, publicados como "Variedades" en la primera página, eran acompañados por sendos folletines: La justicia divina, o el hijo del deshonor, de Wenceslao Ayguals de Iczo, y Caridad cristiana, de Pérez Escrich. "Si no haces mal no esperes bien", de Juana Manuela Gorriti, fue recogido luego en el segundo volumen de Sueños y realidades (Buenos Aires, 1865).

${ }^{30}$ Lila Caimari ha señalado la intromisión de la prensa y de los cronistas o reporteros en la investigación policial de Buenos Aires, tal como ocurría en otras ciudades europeas. Cfr. Lila Caimari, Apenas un delincuente. Crimen, castigo y cultura en la Argentina, 1880-1955 (Buenos Aires: Siglo XXI, 2004), 173-175. Los periódicos locales también reproducían, como hemos visto, famosos casos de criminales europeos. Quizá el de mayor impacto haya sido el de "Jack, The Ripper (Jack, el Destripador)" que, como sabemos, produjo una multiplicación textual y fílmica inconmensurable. Basta decir que durante los años en que se cometieron los crímenes (unos 9 en total), 1888-1891, los diarios de Londres plagaron sus columnas con crónicas, informes policiales, especulaciones de todo tipo, bajo cuyo influjo incluso la policía terminó arrestando equivocadamente a un vendedor de zapatos, confundido (por algunos diarios sensacionalistas) con el Destripador (caso John Pizer). Como ocurrió con Los misterios de París, de Sue, hubo destripadores en Francia, Alemania, Estados Unidos. Una búsqueda digital en el archivo de prensa inglesa del British Newspaper Archive arroja más de 21 mil artículos y notas de prensa referidas a Jack, The Ripper, tan solo en el periodo que va de 1880 a 1899, acceso el 13 de enero de 2021, https://www.britishnewspaperarchive.co.uk. 
Pero cuando se fundó La Patria Argentina en enero de 1879, o, mejor dicho, cuando Eduardo Gutiérrez comenzó a escribir allí sus crónicas policiales, ese procedimiento estaba recién cristalizando. El proceso en esa etapa formativa del propio Gutiérrez ha sido bien estudiado. En efecto, en su indispensable trabajo, Alejandra Laera destacó el subtexto de las crónicas de Tribunales en la formación de la narrativa popular que va de Antonio Larrea al Juan Moreira, y de éste a Hormiga Negra.

Asimismo, Hernán Sosa, en un estudio reciente y minucioso, ha demostrado cómo la escritura que va a definir la larga serie de los folletines criollos de Gutiérrez se forjó en la sección de las crónicas policiales, algunas de las cuales funcionaron como "protofolletines". ${ }^{31}$

Por tanto, antes que esos vínculos, suficientemente explorados, quisiera abordar aquí otro aspecto de los textos de La Patria Argentina, a fin de reforzar nuestra hipótesis sobre el vínculo entre folletín e ilustración: la presencia de imágenes en el zócalo del periódico, imágenes que, por primera vez en la historia de la prensa argentina, acompañan e ilustran los relatos folletinescos que allí se publican. No se trata ya, como ocurría con el Correo del Domingo, de imágenes separadas que remiten a determinadas escenas de una novela publicada en serie y que, como quedó dicho, se enmarcaba en la lógica de las entregas, sino de estampas folletinescas, es decir de imágenes en folletín o, dicho con mayor precisión: de folletines ilustrados. Habría que añadir que se trata de los primeros folletines ilustrados del periódico de los Gutiérrez, y, tal vez, de los primeros folletines ilustrados en la historia de la prensa argentina.

La relevancia de estas imágenes reside, en primer orden, en los destinatarios presumibles o deseables que convoca la publicación. Las ilustraciones, tal como venimos viendo, se constituyen, mediante la práctica editorial del folletín, en un elemento central de las nuevas prácticas de lectura. ${ }^{32}$ Al mismo tiempo, escritor y editor no resultan ajenos a esa demanda inusitada: con el ingreso de

\footnotetext{
${ }^{31}$ Jorge B. Rivera fue el primero en cotejar esos vínculos. No obstante, Alejandra Laera, El tiempo vacío de la ficción. Las novelas argentinas de Eduardo Gutiérrez y Eugenio Cambaceres (Buenos Aires: FCE, 2004) y, más recientemente, Hernán Sosa, La novela gauchesca de Eduardo Gutiérrez. Prensa, discurso judicial y folletín en la génesis de una literatura popular (Buenos Aires: Katatay, 2020), produjeron análisis detallados sobre los folletines de Gutiérrez.

${ }^{32}$ En México, por ejemplo, el periódico El Siglo Diez y Nueve acompañó con algunas ilustraciones la reproducción en su zócalo de Los misterios de París, de Sue. Ver, al respecto, el citado trabajo de Pérez Salas "Las imágenes de Los misterios...", 184-196.
} 
la imagen en los impresos surgen también nuevas prácticas de escritura, puesto que los escritores no podían eludir su proximidad iconográfica que los obligaba, en muchos casos, a modificar su texto. ${ }^{33}$

Estamos ante un fenómeno netamente moderno, expresado a nivel gráfico por el formato magazine que alcanzará su mayor desarrollo hacia el final de la centuria. Fenómeno moderno, en términos tipográficos, y fenómeno popular, en términos de lectura. En este sentido, si el uso de la imagen ha sido generalmente evaluado como un modo de seducción de las culturas populares, según una larga tradición ilustrada que vincula el predominio de lo sensitivo con la carencia de competencias lingüísticas, la decisiva participación letrada y artística (pintores, grabadores, dibujantes, litógrafos) incita a repensar las concepciones de lo popular vinculadas con el mundo del impreso. ${ }^{34}$

Para tal fin, quisiera recuperar un fragmento de un sesudo trabajo de Ángela Dellapiane, el cual, junto con las aproximaciones pioneras de Jorge B. Rivera, es uno de los primeros en afrontar el tema. Dados los puntos implicados, vale la pena citar in extenso:

Siguiendo la moda impuesta por el folletín europeo, los folletines de Gutiérrez, al aparecer como libros, fueron ilustrados: una ilustración forma la carátula y tres van distribuidas -sin correlación con el texto- dentro del libro, con cita al pie, de una línea del texto que es la ilustrada. Las ilustraciones (o grabados, o láminas) servían para hacer los cuadernillos de las entregas, o el volumen, más vendibles. Las que acompañan las primeras -o segundas- ediciones de los folletines de Eduardo Gutiérrez, o sea, las ediciones contemporáneas del autor, son grotescas interpretaciones de las figuras, ropas, escenario, peleas o tormentos del héroe y mueven más a risa que a empatía con las desdichas del hombre. Razones: una industria editorial incipiente, una edición barata destinada a un público sin tradición bibliófila y que ya, desde su exterioridad, indicaba el contenido. ${ }^{35}$

\footnotetext{
${ }^{33}$ Sobre este punto, ver los aportes historiográficos de Michel Melot, "Le texte et l'image", en Histoire de l'édition française. Le temps des éditeurs, ed. de Roger Chartier y Henri-Jean Martin (París: Fayard / Promodis, 1990), 329-355.

${ }^{34} \mathrm{He}$ adelantado algunas premisas sobre el tema al analizar las entregas ilustradas de las novelas de Sue y Dumas en Buenos Aires. Cfr. Pas, "Eugène Sue en Buenos Aires...", 221-223.

${ }_{35}$ Ángela Dellapiane, "Los folletines gauchescos de Eduardo Gutiérrez", Revista Iberoamericana 44, núms. 104-105 (1978): 500.
} 
Es probable que esta sea, con matices, la visión más generalizada de la crítica. Los textos de Gutiérrez cumplieron, al parecer, con el itinerario editorial (europeo) de las novelas de folletín.

Si bien es cierto que la industria editorial argentina comenzaba por entonces a desarrollar su volumen, resulta evidente también que la mirada de Dellapiane (y de la crítica, en general) estuvo orientada por parámetros librescos que desatienden las condiciones materiales de edición y lectura. Por el contrario, si se observa el contexto de edición primigenia comprobamos que lejos de ser un añadido, un agregado para la mejor circulación en su pasaje al libro -lejos entonces de ser el remedo de una "moda"-, las ilustraciones en los relatos de Gutiérrez fueron pensadas y ejecutadas como parte -y una parte no menor, como enseguida veremos- de las entregas.

Juan Moreira, Juan Cuello, El Jorobado, El Tigre de Quequén no sólo fueron los primeros folletines publicados, sino también los primeros folletines ilustrados (a los que podríamos sumar Antonio Larrea, citado al inicio de nuestro trabajo, el primero en ese sentido, sin ser estrictamente un folletín) aparecidos en La Patria Argentina en 1880.

En general, las escenas representadas son episodios clave de la narrativa, que procuran expandir imaginariamente momentos significativos de las historias contadas. Veamos sólo dos ejemplos. La estampa final del Juan Moreira captura de modo sintético el episodio que se convertirá en símbolo de las narrativas ulteriores del moreirismo: el "ajusticiamiento" de Moreira por la espalda, cuando estaba a punto de sortear el muro que lo dejaría en libertad (Imagen 8). Como se recordará, ese es el momento elegido por Leonardo Favio con el que cierra su versión fílmica de 1973. Momento inolvidable: el pasaje del folletinista al cineasta reafirma el sentido ilustrativo, emblemático y dramático de la escena.

La otra estampa también pertenece al cierre dramático de la narración, en este caso al fusilamiento de Juan Cuello, el gaucho federal del rosismo sublevado (Imagen 9). Se trata de una escena, y sobre todo de un escenario, que había sido ya representado (pictórica y literariamente) en ocasiones previas: el Campamento de Santos Lugares (asiento militar de Rosas), donde se alista la tropa de soldados encargada de ajusticiar al condenado. Éste mira desafiante a sus verdugos, en una posición (sentado y cruzado de brazos) que parece doblegar el efecto de reprimenda, darle vuelta, volverlo hacia sus victimarios.

Además del carácter de colofón de estas imágenes, se insertan de modo estratégico en cada entrega final, al punto de que lo que se "ve" replica, sin 
mayores desviaciones, lo que se "lee". Es decir, a diferencia de lo señalado por Dellapiane para la edición en libro, aquí sí hay correlación entre la imagen y el texto. Una correlación, incluso, de acuerdo a los recursos disponibles de entonces, podemos suponer, sumamente estilizada, que busca de modo deliberado duplicar en imágenes lo que el lector va a leer en palabras. ${ }^{36}$

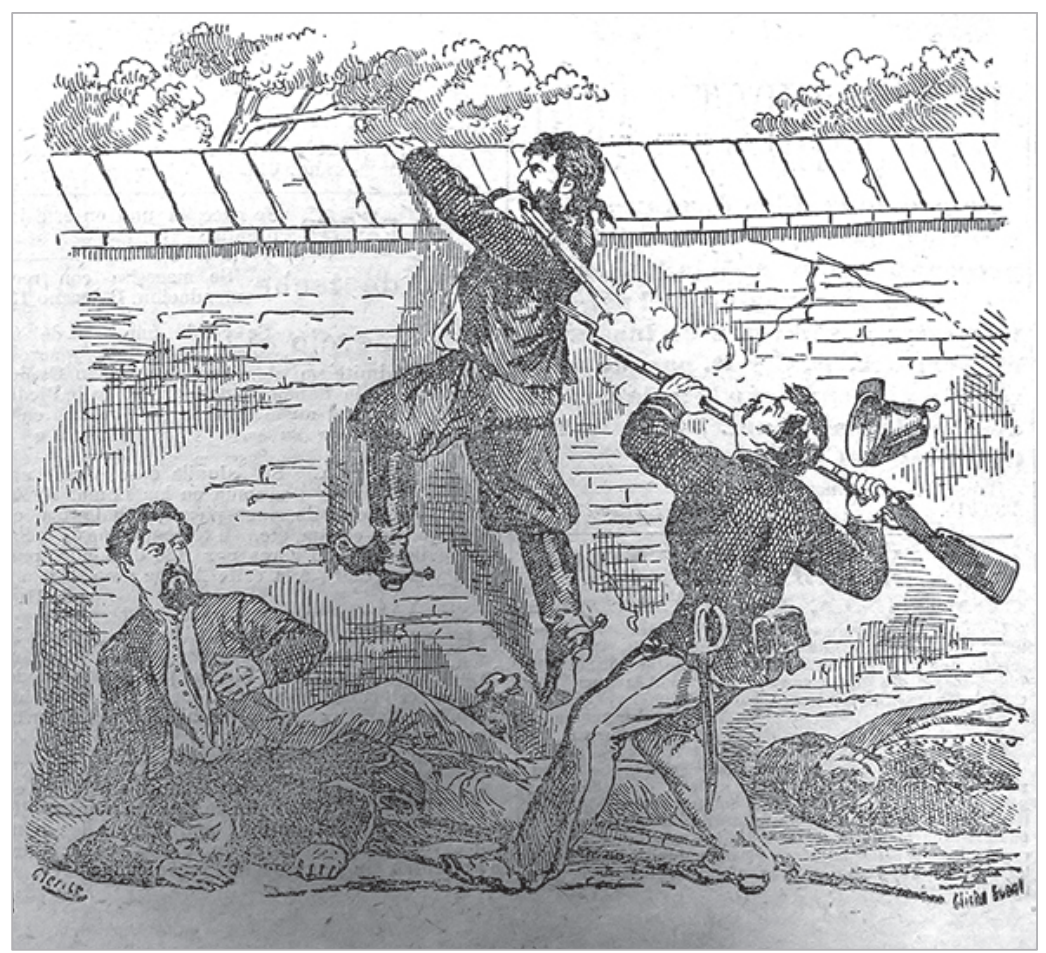

Imagen 8. La Patria Argentina, núm. 372, 7 de enero de 1880.

Penúltima entrega del Juan Moreira.

\footnotetext{
${ }^{36}$ Los encargados de las ilustraciones fueron el dibujante Carlos Clérice y el grabador Supot. No habría que olvidar que el primero comenzó como dibujante de El Mosquito de Henri Stein, y colaboró en el semanario El Correo de las Niñas (típicamente magazinesco) de Ventura Linch; fue, también, quien se encargó de las ilustraciones de la primera edición de La vuelta de Martín Fierro (1879), de José Hernández. Como bien señala Hernán Sosa, las ilustraciones del periódico no siempre fueron incorporadas en ediciones librescas ulteriores. Sí, en cambio, lo fueron las realizadas por la imprenta de La Patria Argentina. Cfr. Sosa, La novela gauchesca, 111.
} 
En consecuencia, cabe leer sus conclusiones desde un punto de vista exactamente inverso: "una industria editorial incipiente" no es causa suficiente de lo "grotesco" de las ilustraciones que acompañaron las novelas de Gutiérrez; por el contrario, la "exterioridad" que "ya" indica el contenido -con ese grado de inminencia que presupone el adverbio entre un formato popular y una ideología de lectura- resulta de la atención (y la adecuación) a un tipo de demanda cada vez más extendida y creciente, que veía en las ilustraciones o estampas un modo de interpelación novedoso, empático (si pensamos en la etimología del término: pathos) y, también, distinto.

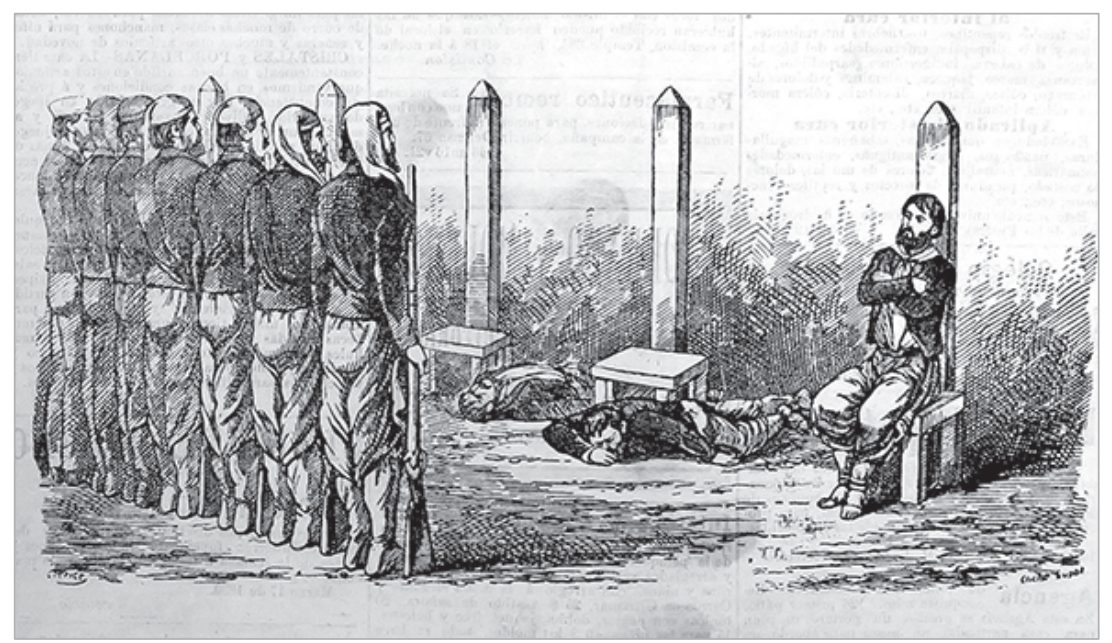

Imagen 9. La Patria Argentina, núm. 444, 19 de marzo de 1880.

Última entrega de Juan Cuello.

\section{Conclusiones}

\section{La máxima visibilidad del folletín}

A partir de la década de 1850, la cultura visual comenzó a expandirse en Buenos Aires -y, en general, en el Río de la Plata-. A mediados de la década, los locales o casas de vistas ópticas (dioramas, panoramas, estereoscopios, daguerrotipos) se habían ya multiplicado como lugares de entretenimiento y ocio de 
la sociabilidad porteña. ${ }^{37}$ Esa propagación de la cultura visual alcanzó desde ya a la prensa, que a partir del invento de la litografía no dejó de acrecentar ofertas de publicaciones ilustradas.

En poco tiempo, las nuevas tecnologías -la fotografía, el cinematógrafoalcanzarían el summum de esa visibilidad máxima. No obstante, en un punto central la pintura se aproxima a la fotografía; ambas llevan la aspiración de captar un instante, de congelar la escena en su momento decisivo; comparten, puede decirse, una ambición de realidad profundamente enraizada en toda tecnología óptica, que es también la soterrada declaración de su artificio. Roland Barthes llamó a esa aspiración numen..$^{38}$ Que la escena final del Juan Moreira transite incólume del folletín a su versión fílmica -es decir, que se inserte en dos versiones si no opuestas, sí notoriamente divergentes- es un indicio de ese poder de captación de las imágenes, de re-presentación.

Josefina Ludmer subrayó que ese virtual pasaje -en el cual se "ve el deseo de un cine futuro"- respondió a una "visibilidad máxima" del proceso modernizador -el reemplazo perentorio del carruaje por el ferrocarril-, cuya modulación misma era producto de la modernización. Una visibilidad máxima sólo asequible "con la ilusión perfecta de realidad de la nueva tecnología de la prensa". ${ }^{39}$

En esa nueva tecnología, el folletín resultó una matriz genérica clave en al menos dos sentidos: popularizó la lectura, y mass-mediatizó la literatura. Para lograrlo, el recurso de las imágenes resultó indispensable. La retórica del folletín se volvía más efectiva a partir de la representación icónica de las imágenes. Hay allí, entre la asimilación de la percepción o la mirada y las competencias lingüísticas, un vínculo inextricable que la semiótica visual ha propuesto como trasposición textual del discurso iconográfico. En síntesis: la imagen es un texto, pero un texto cuya potencia reside en su (aparente) inmediatez. Ahora bien, las imágenes no sólo transmiten de un modo más directo las sensaciones (y emociones) "narrativas", sino que también reformulan (o deberían reformular) las claves de lectura predominantemente textualistas.

\footnotetext{
${ }^{37}$ Roberto Amigo, "Imágenes de la historia y discurso político en el Estado de Buenos Aires (1852-1862)", en Arte argentino de los siglos XVIII y/o XIX (Buenos Aires: Fundación para la Investigación del Arte Argentina, 1998), 11-57.

${ }_{38}^{38}$ Roland Barthes, La cámara lúcida. Notas sobre fotografía (Buenos Aires: Paidós, 1989), 73-74.

${ }^{39}$ Las tecnologías de esa ilusión (de verdad) hacían de Moreira un Billy the Kid o un Jesse James, que aparecieron en Estados Unidos en la década de 1870. Josefina Ludmer, El cuerpo del delito (Buenos Aires: Perfil, 1999), 230-231.
} 


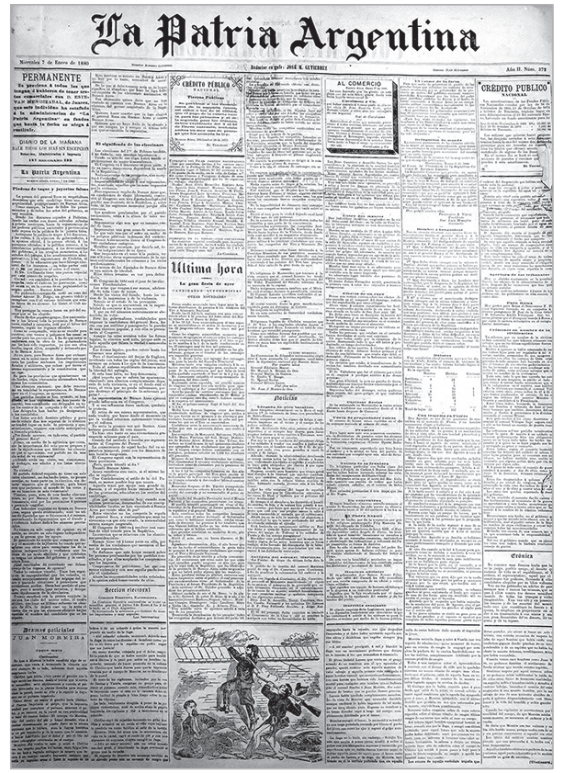

Imagen 10. Primera página de La Patria Argentina, 7 de enero de 1880.

Folletín ilustrado: Juan Moreira.

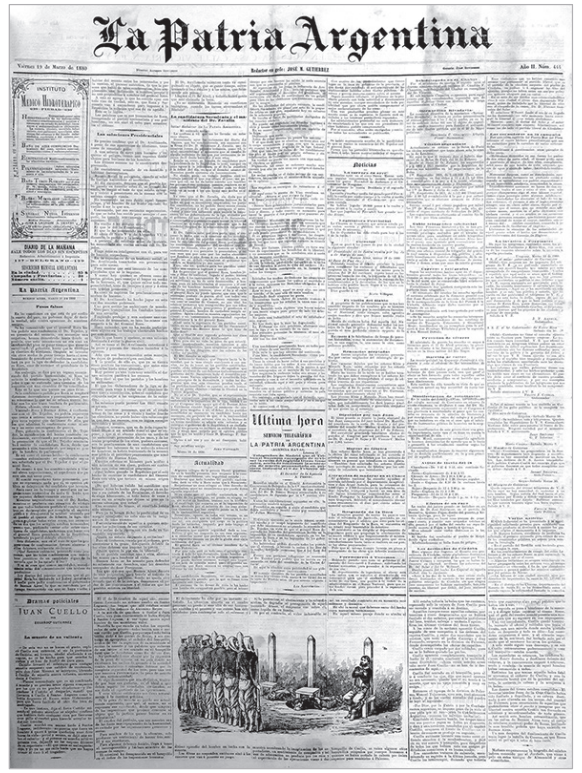

Imagen 11. Primera página de La Patria Argentina, 19 de marzo de 1880.

Folletín ilustrado: Juan Cuello.

Una historia del folletín, por tanto, no debería obviar esa alianza peculiar entre el lenguaje melodramático y la representación pictórica. ${ }^{40}$ Las ilustraciones en los folletines de La Patria Argentina parecen dar cuenta de ese anhelo de "visibilidad máxima" del que hablara Ludmer. La presumible estilización de las estampas, el cuidado con el que fueron ejecutadas sugiere, en cambio, una tensión entre los efectos de la mass-mediatización y las ideologías de la modernización artística y letrada.

Que los folletines gauchescos de Gutiérrez acompañen su éxito con cuidadas imágenes de episodios significativos parecería ser indicio de un tipo de público lector -el suscriptor del diario, en primer orden- acostumbrado a ese tipo de viñetas; un público lector urbano que conoce de antemano (y requiere)

\footnotetext{
${ }^{40}$ Las campañas publicitarias que en París, por ejemplo, recurrían a grandes afiches callejeros y que hacia finales de siglo volverían mucho más sofisticados los anuncios, indican el rol decisivo que cumplieron las imágenes en la masificación de la lectura. Benoît Lenoble, "Les campagnes de lancement de romans-feuilletons: l'exemple du Journal (1892-1935)", Revue d'Histoire Moderne et Contemporaine, núm. 52/1 (2005): 175-197.
} 
el pacto de lectura que ofrece el folletín; un público lector cada vez más extendido al que el diario, sin embargo, sigue todavía confinando al zócalo o subsuelo

del impreso, subestimando el potencial transformador de esa sección, que no tardaría mucho en convertirse (retórica y visualmente) en un formato dominante.

\section{Referencias}

Adamowicz-Hariasz, Maria. "From the Opinion to the Information: The RomanFeuilleton and the Transformation of the Nineteenth-Century Fench Press". En Making the News. Modernity \& the Mass Press in Nineteenth-Century France. Edición de Dean de la Motte y Jeannene M. Przyblyski, 160-184. Amherst: University of Massachusetts Press, 1999.

Amigo, Roberto. "Imágenes de la historia y discurso político en el Estado de Buenos Aires (1852-1862)". En Arte Argentino de los siglos XVIII y/o XIX. Premio Telefónica, 11-57. Buenos Aires: Fundación para la Investigación del Arte Argentina, 1998.

Anderson, Patricia. The Printed Image and the Transformation of Popular Culture 1790-1860. Oxford: Oxford University Press, 1991.

Barthes, Roland. La cámara lúcida. Notas sobre fotografía. Buenos Aires: Paidós, 1989.

Bory, Jean-Louis. Eugène Sue, le roi du roman populaire. París: Hachette, 1962.

Brake, Laurel y Marysa Demoor, eds. The Lure of Illustration in the Nineteenth Century. Picture and Press. Londres; Nueva York: Palgrave MacMillan, 2009.

Cachin, Marie-Françoise. Diana Cooper-Richet, Claire Parfait y Jean-Yves Mollier, dirs. Au bonheur du feuilleton. Naissance et mutations d'un genre (ÉtatsUnis, Grande-Bretagne, XVIIIe-XXe siècles). París: CREAPHIS Éditions, 2007.

Caimari, Lila. Apenas un delincuente. Crimen, castigo y cultura en la Argentina, 1880-1955. Buenos Aires: Siglo XXI, 2004.

Chartier, Roger. "De la historia del libro a la historia de la lectura". En Libros, lecturas y lectores en la Edad Moderna, 26-45. Madrid: Alianza, 1994.

Correo del Domingo (1865-1866).

Dellapiane, Ángela. "Los folletines gauchescos de Eduardo Gutiérrez". Revista Iberoamericana 44, núms. 104-105 (1978): 487-506.

Díaz, José-Luis. "Avatars journalistiques de l'éloquence privée". En La civilisation du journal. Histoire culturelle et littéraire de la presse française au XIXe siècle. Dirección de Dominique Kalifa, Philippe Régnier, Marie-Ève Thérenty y Alain Vaillant, 691-715. París: Nouveau Monde Éditions, 2011. 
Dumas, Alexandre. Crimes célèbres. 8 tomos. París: Administration du Librairie, 1839-1840.

Guise, René. Le roman-feuilleton 1830-1848: la naissance d'un genre. Lille: A.N.R.T., 1985.

Journal des Débats, 19 de junio de 1842.

Kalifa, Dominique. "Usages du faux. Faits divers et romans criminels au XIXe siècle". Annales. Histoire, Sciences Sociales, año 54, núm. 6 (1999): 1345-1362.

Kalifa, Dominique y Marie-Ève Thérenty, dirs. Les mystères urbains au XIXe siècle: circulations, transferts, appropriations. Acceso 13 de enero de 2021, http:// www.medias19.org/index.php?id=17039.

Laera, Alejandra. El tiempo vacío de la ficción. Las novelas argentinas de Eduardo Gutiérrez y Eugenio Cambaceres. Buenos Aires: Fondo de Cultura Económica, 2004.

Lenoble, Benoît. "Les campagnes de lancement de romans-feuilletons: I'exemple du Journal (1892-1935)". Revue d'Histoire Moderne et Contemporaine, núm. 52/1 (2005): 175-197.

Ludmer, Josefina. El cuerpo del delito. Buenos Aires: Perfil, 1999.

Melot, Michel. "Le texte et l'image". En Histoire de l'édition française. Le temps des éditeurs. Edición de Roger Chartier y Henri-Jean Martin, 329-355. París: Fayard / Promodis, 1990.

Meyer, Marlyse. Folhetim. Uma história. São Paulo: Companhia das Letras, 1996. Mitre, Bartolomé. "Folletín". Los Debates, núm. 1 (1o. de abril de 1852).

Munilla Lacasa, María Lía y Georgina G. Gluzman. "Imágenes globales/selecciones locales: las publicaciones periódicas europeas en los diarios porteños. El caso de El Recopilador y Andrea Macaire". En llustrar e imprimir. Una historia de la cultura gráfica en Buenos Aires 1830-1930. Coordinación de Sandra Szir, 23-52. Buenos Aires: Ampersand, 2016.

Pas, Hernán. "Eugène Sue en Buenos Aires. Edición, circulación y comercialización del folletín durante el rosismo". Varia Historia 34, núm. 64 (2018): 193-225.

Pas, Hernán. "La seducción de las imágenes. El ingreso de la litografía y los nuevos modos de publicidad en Latinoamérica". Caracol, núm. 2 (2011): 10-41.

La Patria Argentina (25, 27 de noviembre de 1879; 7 de enero, 19 de marzo de 1880).

Pérez Salas, Ma. Esther. "Las imágenes de Los misterios de París en las ediciones mexicanas". En Tras las huellas de Eugenio Sue. Lectura, circulación y apropiación de Los misterios de París. Siglo XIX. Coordinación y edición de 
Laura Suárez de la Torre, 184-196. México: Instituto de Investigaciones Dr. José María Luis Mora, 2015.

Queffélec-Dumasy, Lise. La querelle du roman-feuilleton. Littérature, presse et politique, un débat précurseur (1836-1848). Grenoble: ELLUG, 1999.

Queffélec-Dumasy, Lise. Le roman-feuilleton français au XIXe siècle. París: PUF, 1989.

Rivera, Jorge B. "El folletín, Eduardo Gutiérrez". Historia de la Literatura Argentina. Buenos Aires: CEAL, 1968.

Roman, Claudia. Prensa, política y cultura visual. El Mosquito (Buenos Aires, 1863-1893). Buenos Aires: Ampersand, 2017.

Sainte-Beuve, Charles A. "De la littérature industrielle". Revue des Deux Mondes 19 (1839): 675-691.

Sosa, Hernán. La novela gauchesca de Eduardo Gutiérrez. Prensa, discurso judicial y folletín en la génesis de una literatura popular. Buenos Aires: Katatay, 2020.

Sozzo, Máximo. "Retratando al 'homo criminalis'. Esencialismo y diferencia en las representaciones 'profanas' del delincuente en la Revista Criminal (Buenos Aires, 1873)". En La ley de los profanos. Delito, justicia y cultura en Buenos Aires (1870-1940). Compilación de Lila Caimari, 23-65. Buenos Aires: Fondo de Cultura Económica, 2007.

Suárez de la Torre, Laura. "Lecturas y lectores de misterios en la Ciudad de México, siglo XIX". En Tras las huellas de Eugenio Sue. Lectura, circulación y apropiación de Los misterios de París. Siglo XIX, 138-159. México: Instituto de Investigaciones Dr. José María Luis Mora, 2015.

Suárez de la Torre, Laura, coord. y ed. Tras las huellas de Eugenio Sue. Lectura, circulación y apropiación de Los misterios de París. Siglo XIX. México: Instituto de Investigaciones Dr. José María Luis Mora, 2015.

Sue, Eugène. Los misterios de París. Edición adornada de cien láminas; traducción de D. A. X. San Martin (Barcelona: Imprenta de Saurí, 1845).

Thérenty, Marie-Ėve. "El folletín en los periódicos del siglo XIX: ¿hecho literario o fenómeno social?". En La invención de la cultura mediática. Prensa, literatura y sociedad en Francia en el siglo XIX, 11-29. México: Instituto de Investigaciones Dr. José María Luis Mora, 2013.

Thérenty, Marie-Ėve y Alain Vaillant. 1836: I'an I de l'ère médiatique. Étude littéraire et historique du journal La Presse d'Émile de Girardin. París: Nouveau Monde Éditions, 2001.

La Tribuna (8-9 de enero, 13-16 de octubre de 1855; $12-13$ de enero, 20-22 de abril de 1857; marzo-julio de 1864). 